\title{
Antimicrobial Activity, Cytotoxicity and Chemical Constituents of the Freshwater Microalga Oscillatoria princeps
}

\author{
Diaa A. Marrez ${ }^{1 *}$ (D), Yousef Y. Sultan ${ }^{1}$, Mohamed M. Naguib ${ }^{1}$, Aziz M. Higazy ${ }^{2}$ \\ 1 Food Toxicology and Contaminants Department, National Research Centre, Cairo, Egypt \\ 2 Microbiology Department, Faculty of Agriculture, Cairo University, Cairo, Egypt \\ * Correspondence: diaamm80@ hotmail.com;
}

Scopus Author ID 56288678900 (D.A.M)

36480540200 (Y.Y.S)

Received: 26.01.2021; Revised: 10.04.2021; Accepted: 14.04.2021; Published: 26.04.2021

\begin{abstract}
The microalgae Oscillatoria sp. are promising sources of bioactive metabolites used in both pharmaceutical and nutraceutical applications. The main objective of present study is to determine the antimicrobial activity, cytotoxicity, and chemical profile of Oscillatoria princeps $\mathrm{r}$ extracts and its fractions. $O$. princeps extracts were prepared by successive extraction method, and chemical constituents were identified using GC-MS. Diethyl ether extract (DEE) had antimicrobial activity against all tested microorganisms and the highest inhibition zones 20.7 and $20.2 \mathrm{~mm}$ was observed against $P$. aeruginosa and $A$. flavus, respectively. Also, DEE showed an anticancer activity with $\mathrm{IC}_{50}$ values of 35.18, 46.6, and $79.18 \mathrm{~g} \mathrm{~m} \mathrm{~m}^{-1}$ against breast cancer (MCF7), colon cancer (HCT116), and hepatocellular carcinoma (HePG2) cell lines, respectively. By DEE fractionation, fraction F7 showed the highest antimicrobial activity followed by fraction F4 with minimum inhibitory concentration (MIC) values ranged between 0.5 and $1.9 \mathrm{mg} \mathrm{ml}^{-1}$. Fraction F4 recorded anticancer activity against HCT116, MCF7, and HePG2 with $\mathrm{IC}_{50}$ of 22.62, 24.43, and $102.52 \mu \mathrm{g} \mathrm{ml}^{-1}$, respectively. While fraction F7 had anticancer activity against HCT116 and MCF7 without any effect on the HePG2 cell line. GC-MS analysis of fractions F4 and F7 represented that the main compounds responsible for the bioactivity were Pentadeconic acid,4-hexadecyl ester, and 9-Octadecenoic acid in F4, while the main compounds in F7 were Quercetin 7,3',4'-trimethoxy and Methyl tetradecanoate. The study concluded that $O$. princeps DEE extract and fractions had a sufficient amount of bioactive compounds that possess antimicrobial and anticancer activity, which could be a promising source for pharmaceutical and nutraceutical ingredients.
\end{abstract}

Keywords: Oscillatoria princeps; antimicrobial activity; cytotoxicity; chemical constituents.

(C) 2021 by the authors. This article is an open-access article distributed under the terms and conditions of the Creative Commons Attribution (CC BY) license (https://creativecommons.org/licenses/by/4.0/).

\section{Introduction}

Natural products are the main source for drug discovery and development. Many microorganisms and plants have a great attraction as a natural source of bioactive molecules [1-6]. Blue-green algae have become an important target for pharmaceutical and biotechnology industries because of the huge number of bioactive compounds with a wide range of biological activities discovered from them [7-11]. Cyanobacteria are prokaryotic forms that use chlorophyll for photosynthesis, therefore many species capable of nitrogen fixation. They can also grow under heterotrophic conditions using the organic carbon substrates as energy sources 
[12-16]. Cyanobacteria are found in many different habitats, from fresh to marine, hyper-saline, and terrestrial ecosystems $[17,18]$.

Oscillatoriaceae is one of the most important orders in blue-green algae. More than 15 species are present in Oscillatoriaceae order like Spirulina, Oscillatoria, Phormidium, andLyngbya. Oscillatoriaceae species produce many forms of biologically and interesting significant bioactive metabolites (more than 300 compounds are reported), which cover almost all of these biological activities [19-21]. Oscillatoria species produce many pharmaceutical and nutraceutical ingredients with varying bioactivities, including antibacterial, antifungal, antioxidant, antialgal, antiviral, anticancer, and anti-inflammatory effects [22]. These bioactive ingredients ranged between phenolic compounds, alkaloids, fatty acid, pigments and pigments derivatives, linear and cyclic peptides, terpenoids, and N-glycosides [23-27]. The present study aimed to determine the antimicrobial activity, cytotoxicity, and chemical profile of Oscillatoria princeps diethyl ether extract (DEE) and its fractions. The present study aimed to observe the pharmaceutical, food preservation, and nutraceutical activity of Oscillatoria princeps extracts by evaluating the antimicrobial and anticancer activities of these extracts and their fractions. Followed by the identification of the chemical profile of bioactive fractions using GC-MS.

\section{Materials and Methods}

\subsection{Microalgae strain and culture medium.}

A pure isolate of Oscillatoria princeps was obtained from Marine Toxins Lab., National Research Centre, Egypt [28]. The culture medium used for cultivation was BG-11 [29]. At the maximum growth phase, 21 days, $O$. princeps biomass was harvested and dried overnight in a hot air oven at $50^{\circ} \mathrm{C}$.

\subsection{Preparation of $O$. princeps extracts.}

The dried $O$. princeps biomass ( $100 \mathrm{~g}$ ) was successive extraction using several solvents according to the polarity (hexane, diethyl ether, chloroform, acetone, ethyl acetate, ethanol, methanol, and deionized water). Each homogenized dried biomass was sonicated for 20 min using an ultrasonic micro tip probe of 400 watts (ULTRASONIC Get 750), then centrifuged at $4500 \mathrm{rpm}$ for $10 \mathrm{~min}$ (SIGMA Laborzentrifugen Gmbh). Supernatants were collected separately, and the pellets were re-extracted twice, as mentioned before. Combined supernatants were evaporated to dryness at $40^{\circ} \mathrm{C}$ using a rotary evaporator. Dried extracts were kept in labeled sterile vials in a deep freezer at $-20^{\circ} \mathrm{C}$ till further use [7].

\subsection{Fractionations of $O$. princeps crude extract.}

The diethyl ether extracts (DEE) was fractionated using column chromatography technique. Glass column $(30 \times 500 \mathrm{~mm})$ was initially packed with $5 \mathrm{~g}$ of anhydrous sodium sulfate followed by $30 \mathrm{~g}$ of silica gel (0.06 - $0.2 \mathrm{~mm}, 70$ - 230 mesh ASTM) using chloroform as a carrier solvent to create a slurry. Finally, $5 \mathrm{~g}$ of anhydrous sodium sulfate was added to the silica gel's top to prevent the column from drying. A portion of DEE $(500 \mathrm{mg})$ in $10 \mathrm{ml}$ chloroform was loaded to the column and allowed to flow at a rate of a drop $\sec ^{-1}$. The silica gel column was eluted with different mixture (v/v) of chloroform: methanol (98:2), (95:5), (90:10), (80:20), (50:50), (25:75) and finally methanol 100\% to give 7 fractions. The fractions, $50 \mathrm{ml}$ each, were collected, evaporated under vacuum, and stored for further analysis and bioassays [19]. 


\subsection{GC/MS analysis of $O$. princeps bioactive fractions.}

The diethyl ether fraction F4 and F7 were subjected to analysis of chemical composition using GC/MS, Thermo Scientific, Trace GC Ultra coupled with ISQ Single Quadrupole mass spectrometer (MS). Components were separated using TG-5MS fused silica capillary column (30 m, $0.251 \mathrm{~mm}, 0.1 \mathrm{~mm}$ film thickness). Helium was used as carrier gas at a constant flow rate of $1 \mathrm{ml} \mathrm{min}^{-1}$. The injector and MS transfer line temperature was set at $280{ }^{\circ} \mathrm{C}$. The oven temperature program was started at $50^{\circ} \mathrm{C}$ for $2 \mathrm{~min}$. Then the temperature was ramped to 150 ${ }^{\circ} \mathrm{C}$ at $7{ }^{\circ} \mathrm{C} \mathrm{min}^{-1}$, then to $270{ }^{\circ} \mathrm{C}$ at $5^{\circ} \mathrm{C} \mathrm{min}^{-1}$ and held for $2 \mathrm{~min}$, finally to $310^{\circ} \mathrm{C}$ at $3.5^{\circ} \mathrm{C} \mathrm{min}-$ ${ }^{1}$ and held for $10 \mathrm{~min}$. Mass Spectra were recorded under ionization energy of $70 \mathrm{eV}$ [30]. Tentative identification of the compounds was performed based on comparing their relative retention time and mass spectra with those of the NIST, WILLY library data of the GC/MS system. The quantification of all the identified components was investigated using a percent relative peak area.

\subsection{Antimicrobial activity of $O$. princeps crude extract and fractions.}

\subsubsection{Test microorganisms.}

The inhibitory effect of $O$. princeps crude extracts and fractions was carried out against six strains of foodborne pathogenic bacteria. Two Gram-positive bacteria Staphylococcus aureus ATCC 13565, Bacillus cereus EMCC 1080, and four Gram-negative bacteria Escherichia coli 0157 H7 ATCC 51659, Salmonella typhi ATCC 25566, Pseudomonas aeruginosa NRRL B-272, and Klebsiella pneumoniae LMD 7726. Nine fungal strains were used for the antifungal assay, Aspergillus flavus NRRL 3357, A. parasiticus SSWT 2999, A. ochraceus ITAL 14, A. westerdijikia CCT 6795, A. steynii IBT LKN 23096, A. carbonarius ITAL 204, Fusarium verticillioides ITEM 10027, F. proliferatum MPVP 328 and Penicillium verrucosum BFE 500.

\subsubsection{Disc diffusion assay.}

From the $24 \mathrm{~h}$ incubated nutrient agar slant of each bacterial strain, a full loop of the bacteria was inoculated in a tube containing $5 \mathrm{ml}$ of tryptic soy broth. The broth culture was

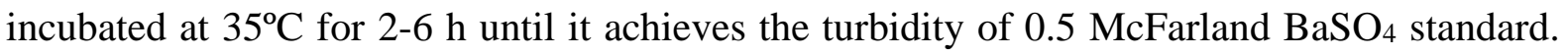
The inhibitory effect of $O$. princeps crude extracts and its fractions were tested against all the tested bacterial species using the disc diffusion method of Kirby-Bauer technique [31-33]. A concentration of $10 \mathrm{mg} \mathrm{ml}^{-1}$ for each extract and fraction was in $1 \mathrm{ml}$ of dimethyl sulfoxide (DMSO). DMSO represented the negative control, and tetracycline $\left(500 \mathrm{mg} \mathrm{ml}^{-1}\right)$ was used as a positive control. The inoculated plates were incubated at $37^{\circ} \mathrm{C}$ for $24 \mathrm{~h}$. After incubation, the inhibition zones were measured and expressed as the clear zone's diameter, including the diameter of the paper disc.

The fungal strains were plated onto potato dextrose agar (PDA) and incubated for 5 days at $25^{\circ} \mathrm{C}$. The spore suspension $\left(2 \times 10^{8} \mathrm{cfu} \mathrm{ml}^{-1}\right)$ of each fungus was prepared in $0.01 \%$ Tween 80 solution by comparing with the $0.5 \mathrm{McFarland}$ standard. Commercial fungicide Nystatin (1000 Unit $\mathrm{ml}^{-1}$ ) and DMSO considered positive and negative control, respectively. The inoculated plates were incubated at $25^{\circ} \mathrm{C}$ for $48 \mathrm{~h}$, then the antifungal activity was assessed by measuring the zone of inhibition $(\mathrm{mm})$ [34]. The results average was calculated from at least three replicates for each assay. 
2.5.3. Determination of minimum inhibitory concentration (MIC).

The determination of MIC was conducted using the micro broth dilution method as of Andrews [35]. Two-fold serial dilutions of $O$. princeps ether extract and fractions with nine different concentrations of each $O$. princeps ether extract and fractions $(4.0,2.0,1.75,1.5,1.0$, $0.75,0.50,0.25,0.1 \mathrm{mg} \mathrm{ml}^{-1}$ in DMSO) were prepared. Each tube was inoculated with $100 \mathrm{ml}$ of bacterial cell suspension and incubated at $37^{\circ} \mathrm{C}$ for $24 \mathrm{~h}$. Equal volumes of tested bacteria $\left(10^{5} \mathrm{cfu} \mathrm{ml}^{-1}\right)$ were added to each well. MIC values were taken as the lowest concentration of the antimicrobial agent that inhibited bacterial growth after $24 \mathrm{~h}$ incubation at $37^{\circ} \mathrm{C}$.

MIC against fungi was performed by using the technique of Perrucci et al. [36]. Crude extracts and fractions at different concentrations were separately dissolved in $0.5 \mathrm{ml}$ of $0.1 \%$ Tween 80, then mixed with $9.5 \mathrm{ml}$ of melting, $45^{\circ} \mathrm{C}$, PDA, and poured into Petri dish $(6 \mathrm{~cm})$. The prepared plates were centrally inoculated with $3 \mathrm{ml}$ of fungal suspension $\left(10^{8} \mathrm{cfu} \mathrm{ml}^{-1} ; 0.5\right.$ McFarland standard). The plates were incubated at $25{ }^{\circ} \mathrm{C}$ for $24-48 \mathrm{~h}$. At the end of the incubation period, mycelial growth was monitored, and MIC was determined.

\subsection{In vitro cytotoxicity assay of $O$. princeps ether extract and fractions.}

The cytotoxic activity test (In vitro assay) on three human cancer cell lines, colon cancer (HCT116), hepatocellular carcinoma (HepG2), and breast cancer (MCF7) were conducted and assessed by the Bioassay-Cell Culture Laboratory, National Research Centre. The cytotoxicity evaluation of $O$. princeps extracts and their fractions was examined using the colorimetric method of Mosmann [37]. Cell proliferation assay was performed via 3-(4,5dimethylthiazol-2-yl)-2,5-diphenyl tetrazolium bromide (MTT). MTT (0.5 $\left.\mathrm{mg} \mathrm{ml}^{-1}\right)$ was prepared, and MTT solution was added to each of the 96-well microtiter plastic plates. The viability of cancer cells was assessed by reducing the yellow dye (MTT) to purple formazan product. The absorbance was then measured using a microplate multi-well reader (Bio-Rad Laboratories Inc., model 3350, Hercules, California, USA) at $595 \mathrm{~nm}$ and a reference wavelength of $620 \mathrm{~nm}$. A statistical significance was tested between samples and negative control (cells with the vehicle) using the dependent $\mathrm{t}$ - test by the SPSS 11 program. DMSO is the vehicle used to dissolve plant extracts, and its final concentration on the cells was less than $0.2 \%$. The percentage of change in viability was calculated according to the formula:

\section{$\{($ Reading of extract / Reading of negative control $)-1\} \times 100$}

Probit analysis was carried for $\mathrm{IC}_{50}$ and $\mathrm{IC}_{90}$ determination using SPSS 16.0 program.

\subsection{Statistical analysis.}

Statistical significance was determined using Statistica Version 9 (StateSoft, Tulsa, Okla., USA). The means were determined by analysis of variance $(\mathrm{p}<0.05)$, and followed by Fisher's LSD (Least significant differences) method $(\alpha=0.05)$ to compare significant differences between treatments.

\section{Results and Discussion}

\subsection{Antimicrobial activity of $O$. princeps crude extracts.}

Table 1 illustrates the antibacterial activity of $O$. princeps extracts against different species of foodborne pathogenic bacteria. It is clear that the diameter of the inhibition zone 
depends on the form of solvent used and the tested pathogenic bacteria. The diethyl ether extracts of $O$. princeps showed the highest antibacterial activity against $P$. aeruginosa and $B$. cereus, which recorded 20.7 and $20.2 \mathrm{~mm}$ inhibition zones, respectively. Diethyl ether extract has antibacterial activity against all tested pathogenic bacteria, followed by ethanol extract, which has antibacterial activity against all tested bacteria except $K$. pneumonia, and chloroform extract, which has antibacterial activity against all tested bacteria except $S$. typhi. While aqueous extract has no activity against all tested bacteria, followed by methanol extract, which has antibacterial activity only against $K$. pneumonia, and acetone extract, which has antibacterial activity against $S$. aureus and B. cereus.

The antifungal activity of $O$. princeps extracts against different mycotoxigenic fungi species is shown in Table 2. The diethyl ether extracts of $O$. princeps showed the best antifungal activity against all tested fungi achieving an inhibition zone in a range between $7.3 \mathrm{~mm}$ against $P$. verrucosum to $15.7 \mathrm{~mm}$ against $A$. westerdijikia. A. flavus was the most sensitive fungus affected by all extracts, recording an inhibition zone between 9.7 and $14.3 \mathrm{~mm}$. However, $A$. ochraceus was tolerant of resistance to all $O$. princeps extracts except diethyl ether extract, which had an inhibition zone of $7.7 \mathrm{~mm}$.

Mathivanan et al. [38] found that $O$. princeps ethanol, acetone, methanol, and aqueous extracts had antibacterial activity against $S$. aureus, $P$. aeruginosa, and $B$. subtilis being the ethanolic extract as the best. Al-Rubaiee and Shaukat [39] reported that $O$. princeps extract of mixture chloroform: methanol (2:1) had antibacterial activity against $S$. aureus, B. subtilis, $K$. pneumonia, $P$. aeruginosa, and E. coli. They found that the highest antibacterial activity was against $S$. aureus with an inhibition zone of $30 \mathrm{~mm}$, followed by $B$. subtilis and P. aeruginosa with 28 and $25 \mathrm{~mm}$ inhibition zone, respectively. Marrez et al. [19] revealed that Oscillatoria brevis chloroform and diethyl ether extracts had antibacterial activity against $B$. subtilis, $S$. aureus, E. coli, S. typhi, P. aeruginosa and $K$. pneumoniae with a zone of inhibition ranged between 8 and $32 \mathrm{~mm}$. Also, Rath and Priyadarshan [40] reported that the diethyl ether extract Oscillatoria sp. had the least activities towards Gram +ve bacteria B. subtilis and S. aureus and moderate activities towards Gram -ve bacteria $P$. aeruginosa and E. coli whereas methanolic extract of Oscillatoria sp. gave the highest biological activity against B. subtilis, S. aureus, $P$. aeruginosa, and E. coli followed by acetone.

Abd El-Aty et al. [41] reported that all tested strains, E. coli, S. aureus, S. typhi, and $P$. aeruginosa showed higher sensitivity acetone extract of Oscillatoria agardhii. At the same time, the methanol extract showed moderate activity against all bacteria all species. They also reported the ineffectiveness of aqueous extracts against tested bacterial species except for $E$. coli. Selim et al. [42] found that Oscillatoria sp. ethanolic and methanol extracts had antibacterial activity; their effect varied depending on bacterial species. Ethanolic extract showed the highest inhibition zone against $S$. aureus, B. subtilis, and E. coli, respectively, while its methanolic extracts showed the highest activity against E. coli, S. aureus, and B. subtilis, respectively. Khairy and El-Kassas [43] studied the Antifungal activity of Oscillatoria angustissima ethyl acetate, chloroform, methanol, diethyl ether aqueous extracts against Aspergillus niger and Aspergillus flavus. Only ethyl acetate and chloroform extract among these extracts have antifungal activity against $A$. niger and $A$. flavus. Few studies examined the antifungal activity of $O$. princeps extracts. 
Table 1. Antibacterial activity of Oscillatoria princeps crude extracts.

\begin{tabular}{|c|c|c|c|c|c|c|c|c|c|c|}
\hline \multirow{2}{*}{ Bacteria } & \multicolumn{10}{|c|}{ Inhibition zone mm (Mean $\pm *$ S.E) } \\
\hline & -ve control & +ve control & Aqueous & $\mathrm{MeOH}$ & EtOH & Acetone & $\mathrm{CH}_{3} \mathrm{Cl}$ & DEE & EtOA & Hexane \\
\hline B. cereus & 0 & $16.8 \pm 0.86^{\mathbf{b}}$ & 0 & 0 & $7.8 \pm 1.04^{\mathrm{d}}$ & $8.0 \pm 0.50^{\mathrm{d}}$ & $9.3 \pm 0.58^{c}$ & $20.2 \pm 0.76^{\mathrm{a}}$ & $8.3 \pm 0.29^{\mathrm{d}}$ & 0 \\
\hline S. aureus & 0 & $17.2 \pm 1.04^{\mathrm{b}}$ & 0 & 0 & $7.3 \pm 0.28^{d}$ & $8.0 \pm 1.15^{\mathrm{d}}$ & $7.3 \pm 0.58^{\mathrm{d}}$ & $19.5 \pm 2.18^{\mathrm{a}}$ & $9.8 \pm 1.04^{c}$ & $9.2 \pm 1.04^{\mathrm{c}}$ \\
\hline E. coli & 0 & $18.6 \pm 1.28^{\mathrm{a}}$ & 0 & 0 & $10.0 \pm 1.29^{\mathbf{b}}$ & 0 & $8.7 \pm 1.04^{\mathbf{b c}}$ & $19.0 \pm 1.32^{\mathrm{a}}$ & $9.0 \pm 0.32^{\mathbf{b c}}$ & $8.5 \pm 0.5^{\mathrm{c}}$ \\
\hline S. typhi & 0 & $15.5 \pm 1.00^{\mathbf{b}}$ & 0 & 0 & $8.7 \pm 0.58^{\mathrm{c}}$ & 0 & 0 & $17.3 \pm 1.25^{\mathrm{a}}$ & 0 & 0 \\
\hline P. aeruginosa & 0 & $19.8 \pm 1.14^{\mathrm{a}}$ & 0 & 0 & $8.8 \pm 1.25^{\mathrm{c}}$ & 0 & $9.7 \pm 0.28^{\mathbf{b}}$ & $20.7 \pm 2.08^{\mathrm{a}}$ & $9.7 \pm 1.44^{\mathbf{b}}$ & $8.3 \pm 1.15^{\mathrm{c}}$ \\
\hline K. pneumonia & 0 & $18.6 \pm 1.58^{\mathrm{a}}$ & 0 & $8.5 \pm 0.50^{\mathrm{d}}$ & 0 & 0 & $10.0 \pm 0.86^{c}$ & $14.7 \pm 1.25^{\mathrm{b}}$ & 0 & 0 \\
\hline
\end{tabular}

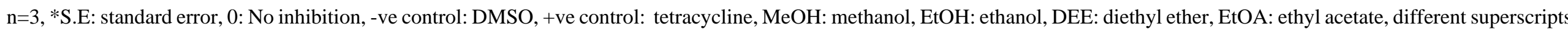
within row are significantly different at the $5 \%$ level.

Table 2. Antifungal activity of Oscillatoria princeps crude extracts.

\begin{tabular}{|c|c|c|c|c|c|c|c|c|c|c|}
\hline \multirow{2}{*}{ Fungi } & \multicolumn{10}{|c|}{ Inhibition zone mm $($ Mean $\pm *$ S.E $)$} \\
\hline & -ve control & +ve control & Aqueous & $\mathrm{MeOH}$ & EtOH & Acetone & $\mathrm{CH}_{3} \mathrm{Cl}$ & DEE & EtOA & Hexane \\
\hline A. flavus & 0 & $15.8 \pm 0.58^{\mathrm{a}}$ & $12.0 \pm 1.04^{\mathbf{b}}$ & $10.7 \pm 0.75^{\mathrm{c}}$ & $10.3 \pm 1.04^{\mathrm{c}}$ & $10.2 \pm 1.50^{\mathrm{c}}$ & $12.2 \pm 0.76^{\mathbf{b}}$ & $14.3 \pm 2.29^{\mathrm{ab}}$ & $9.8 \pm 1.25^{\mathrm{c}}$ & $9.7 \pm 0.58^{c}$ \\
\hline A. niger & 0 & $8.5 \pm 0.36^{\mathrm{c}}$ & 0 & $9.0 \pm 1.29^{\mathrm{c}}$ & 0 & $10.2 \pm 125^{b}$ & $11.3 \pm 1.04^{\mathrm{a}}$ & $10.5 \pm 1.32^{\mathbf{b}}$ & $9.7 \pm 1.15^{b}$ & $7.8 \pm 0.28^{\mathrm{d}}$ \\
\hline A. ochraceus & 0 & $10.8 \pm 0.76^{\mathrm{a}}$ & 0 & 0 & 0 & 0 & 0 & $7.7 \pm 1.25^{\mathrm{b}}$ & 0 & 0 \\
\hline A. parasiticus & 0 & $11.8 \pm 1.04^{\mathbf{b}}$ & 0 & 0 & 0 & 0 & $9.8 \pm 1.04^{\mathrm{c}}$ & $14.8 \pm 0.76^{\mathrm{a}}$ & $8.5 \pm 0.86^{\mathrm{d}}$ & 0 \\
\hline A. westerdijikia & 0 & $10.8 \pm 0.86^{\mathbf{b}}$ & $9.5 \pm 0.86^{\mathrm{c}}$ & 0 & $8.5 \pm 0.87^{\mathrm{d}}$ & 0 & 0 & $15.7 \pm 1.61^{\mathrm{a}}$ & $8.0 \pm 0.86^{\mathbf{d}}$ & 0 \\
\hline A. carbonarus & 0 & $10.5 \pm 0.50^{\mathrm{a}}$ & 0 & $8.7 \pm 0.28^{b}$ & 0 & 0 & 0 & $11.3 \pm 0.76^{\mathrm{a}}$ & $9.2 \pm 0.76^{\mathbf{b}}$ & 0 \\
\hline F. verticelloides & 0 & $11.2 \pm 0.68^{\mathbf{b}}$ & $7.8 \pm 0.28^{\mathrm{c}}$ & $8.3 \pm 1.04^{\mathrm{c}}$ & 0 & 0 & 0 & $13.5 \pm 0.60^{\mathrm{a}}$ & 0 & $11.7 \pm 0.76^{\mathbf{b}}$ \\
\hline F. proleferatum & 0 & $10.9 \pm 0.58^{\mathbf{b}}$ & 0 & 0 & 0 & $9.8 \pm 1.15^{\mathrm{c}}$ & $9.2 \pm 1.04^{\mathrm{c}}$ & $15.0 \pm 1.50^{\mathrm{a}}$ & 0 & 0 \\
\hline P. verrucosum & 0 & $10.1 \pm 1.14^{\mathrm{a}}$ & 0 & $8.5 \pm 0.86^{\mathbf{b}}$ & $7.7 \pm 0.58^{c}$ & 0 & 0 & $7.3 \pm 0.58^{c}$ & 0 & 0 \\
\hline
\end{tabular}

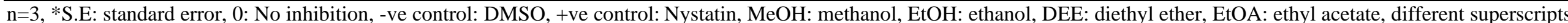
within row are significantly different at the $5 \%$ level. 
Mathivanan et al. [38] found that $O$. princeps ethanol, acetone, methanol, and aqueous extracts have antifungal activity against $A$. niger. However, they reported that the ethanolic extract showed the highest inhibition zone, $14 \mathrm{~mm}$. No inhibition was observed in the current study using ethanol extract against $A$. niger.

Also, Rath and Priyadarshanl [40] reported that methanol, acetone and diethyl ether extracts of $O$. boryana and Oscillatoria sp. have antifungal activity against $A$. niger. Haggag et al. [44] $\mathrm{r}$ eported that $O$. agardhii acetone, methanol, and aqueous extracts had antifungal activity against mycotoxigenic fungi Fusarium moniliforme, $F$. proliferatum, $F$. graminearum, Penicillium digitatum, Aspergillus niger, and A. flavus. Rajendran et al. [45] found that methanol, ethanol, chloroform, and acetone extracts of Oscillatoria sp. had antifungal activity against Fusarium sp. The methanolic and ethanolic extracts showed higher antifungal activity, whereas the chloroform and acetone extracts showed moderate activity. Marrez et al. [19] examined the antifungal activity of several $O$. brevis extracts and found that diethyl ether extract had the highest antifungal activity against $F$. proliferatum, $F$. verticillioides, $P$. verrucosum, A. flavus, A. steynii, A. ochraceus, A. parasiticus, A. westerdijikia, A. carbonarius.3.2. Cytotoxic activity of $O$. princeps diethyl ether extract.

The cytotoxicity of $O$. princeps diethyl ether extract against HePG2, HCT116, and MCF7 cell lines is represented in Fig. 1. A small concentration of ether extract, showed high inhibition against MCF7 and HCT116 cell lines at IC 50 of 35.18 and $46.6 \mu \mathrm{g} \mathrm{ml}^{-1}$, respectively, while moderate anticancer bioactivity was illustrated against $\mathrm{HePG}_{2}$ cell lines with $\mathrm{IC}_{50}$ of $79.18 \mu \mathrm{g} \mathrm{ml}^{-1}$.

Mevers et al. [46] reported that the methanolic extract of Oscillatoria terebriformis had a cytotoxicity effect against A549 lung cancer cells with $\mathrm{IC}_{50}$ of $31.25 \mu \mathrm{g} \mathrm{ml}^{-1}$. Shanab et al. [47] revealed that Oscillatoria sp. aqueous extract recorded high anticancer activity $77.8 \%$ against liver cancer cell line HepG2 at $100 \mu \mathrm{g} \mathrm{ml}^{-1}$. Maruthanayagam et al. [48] found that the mixture of chloroform: methanol (1:1) extract of Oscillatoria sp., O. formosa, O. laetevirens, and $O$. salina showed moderate cytotoxicity with $\mathrm{IC}_{50}$ values from 167 to $325 \mu \mathrm{g} \mathrm{ml}^{-1}$ against Artemia salina. In contrast, they found that these extracts have not any activity against HT29 colon, HoP62 lung, MCF7 breast, and KB oral cell line at concentration reach to $10 \mu \mathrm{g} \mathrm{ml}^{-1}$. Also, Nair and Bhimba [49] reported that Oscillatoria boryana ethanolic extract showed anticancer activity against human breast cancer cell lines MCF7 with IC50 of $10.45 \mu \mathrm{g} \mathrm{ml}^{-1}$. Mukund et al. [50] indicated that Oscillatoria margaritifera dichloromethane and methanolic extracts affected lung cancer cell lines with $\mathrm{IC}_{50}$ of $0.14 \mu \mathrm{M}$. Marrez et al. [19] indicated that Oscillatoria brevis diethylether extracts had a high inhibitory effect against HCT116 and MCF7 cell lines with $\mathrm{IC}_{50}$ values of 22 and $39.7 \mu \mathrm{g} \mathrm{ml}^{-1}$, respectively and moderated anticancer activity against $\mathrm{HePG} 2$ cell line with $\mathrm{IC}_{50}$ value $83.4 \mu \mathrm{g} \mathrm{ml}^{-1}$.

\subsection{Antimicrobial activity $O$. princeps diethyl ether fractions.}

The antibacterial activity of $O$. princeps diethyl ether fractions is represented in Table 3. Fraction F7 had antibacterial activity against all tested foodborne pathogenic bacteria followed by $\mathrm{F} 4$, which had bioactivity against all tested bacteria except $B$. cereus and $K$. pneumonia, while F3 had antibacterial activity only against $S$. aureus and $S$. typhi. In contrast, F1, F2, F5, and F6 showed no antibacterial activity against all tested bacteria. The highest antibacterial activity was showed using F7 against $S$. aureus and $P$. aeruginosa with an inhibition zone of $9.7 \mathrm{~mm}$. 
Table 4 illustrates the antifungal activity of $O$. princeps against toxic fungi. No fraction had antifungal activity against all tested fungi. Fraction F7 showed antifungal activity against all tested fungi except $A$. flavus, followed by F4, which had activity against all tested fungi except $A$. parasiticus and $P$. verrucosum. Whereas F1 and F2 showed no antifungal activity against all tested fungi. The highest inhibition zone, $9.3 \mathrm{~mm}$, was observed using F4 against $A$. carbonarus.

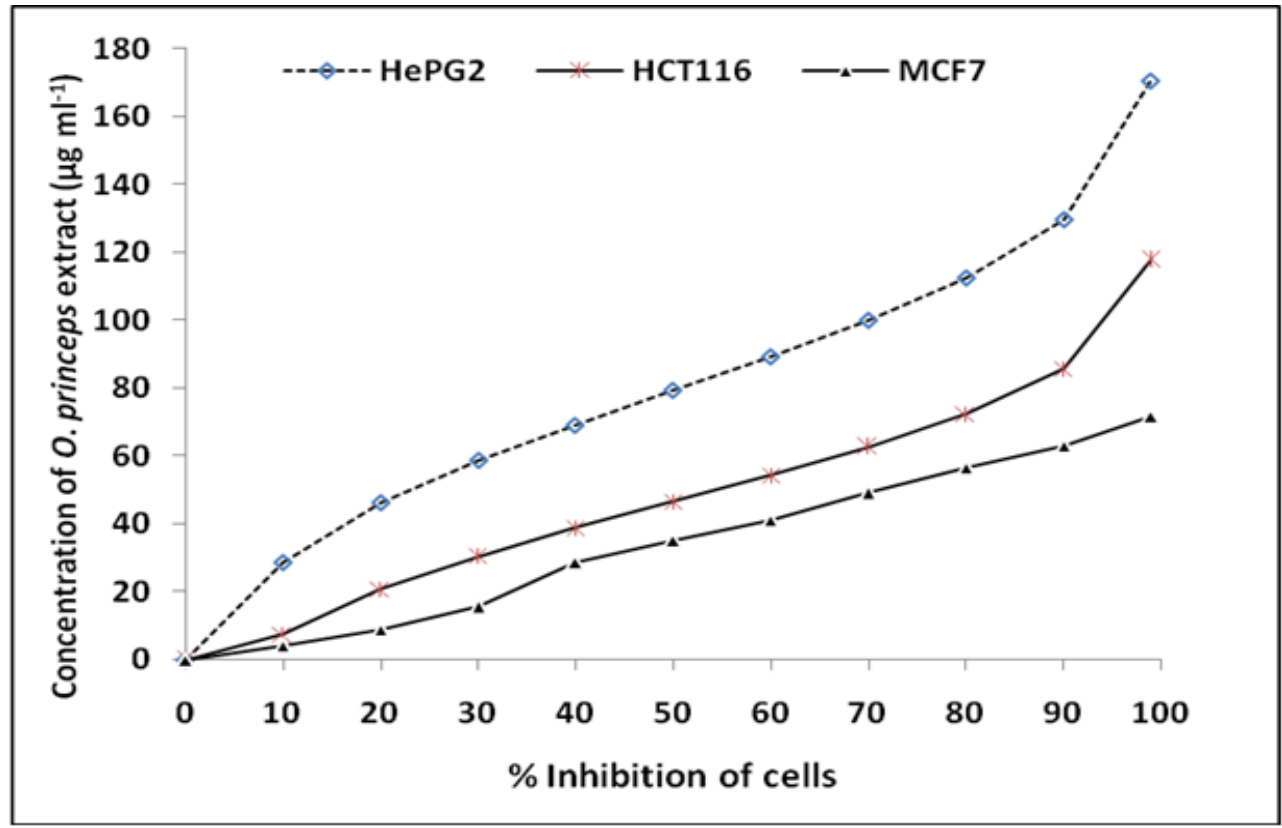

Figure 1. Cytotoxicity of $O$. princeps diethyl ether extract on HePG2, HCT116, and MCF7 cell lines.

Table 3. Antibacterial activity of Oscillatoria princeps DEE extracts fractions.

\begin{tabular}{l|c|c|c|c|c|c|c|c|c}
\hline \multirow{2}{*}{ Bacteria } & \multicolumn{9}{|c}{ Inhibition zone mm $($ Mean $\pm *$ S.E) } \\
\cline { 2 - 10 } & -ve control & - ve control & F1 & F2 & F3 & F4 & F5 & F6 & F7 \\
\hline B. cereus & 0 & $16.5 \pm 0.50^{\mathbf{a}}$ & 0 & 0 & 0 & 0 & 0 & 0 & $9.0 \pm 1.15^{\mathbf{b}}$ \\
\hline S. aureus & 0 & $17.0 \pm 1.00^{\mathbf{a}}$ & 0 & 0 & $8.3 \pm 1.52^{\mathbf{c}}$ & $7.7 \pm 1.15^{\mathbf{d}}$ & 0 & 0 & $9.7 \pm 0.58^{\mathbf{b}}$ \\
\hline E. coli & 0 & $18.8 \pm 1.14^{\mathbf{a}}$ & 0 & 0 & 0 & $8.0 \pm 1.00^{\mathbf{b}}$ & 0 & 0 & $8.0 \pm 0.00^{\mathbf{b}}$ \\
\hline S. typhi & 0 & $15.2 \pm 0.86^{\mathbf{a}}$ & 0 & 0 & $7.7 \pm 0.58^{\mathbf{c}}$ & $8.0 \pm 1.00^{\mathbf{c}}$ & 0 & 0 & $9.0 \pm 1.73^{\mathbf{b}}$ \\
\hline $\boldsymbol{P}$. aeruginosa & 0 & $19.5 \pm 1.08^{\mathbf{a}}$ & 0 & 0 & 0 & $7.7 \pm 1.15^{\mathbf{c}}$ & 0 & 0 & $9.7 \pm 1.88^{\mathbf{b}}$ \\
\hline K. pneumonia & 0 & $18.4 \pm 1.28^{\mathbf{a}}$ & 0 & 0 & 0 & 0 & 0 & 0 & $7.3 \pm 0.58^{\mathbf{b}}$ \\
\hline
\end{tabular}

$\mathrm{n}=3$, *S.E: standard error, 0: No inhibition, -ve control: DMSO, +ve control: tetracycline, different superscripts within row are significantly different at the $5 \%$ level.

Table 4. Antifungal activity of Oscillatoria princeps DEE extracts fractions.

\begin{tabular}{|c|c|c|c|c|c|c|c|c|c|}
\hline \multirow{2}{*}{ Fungi } & \multicolumn{9}{|c|}{ Inhibition zone mm (Mean $\pm *$ S.E) } \\
\hline & -ve control & -ve control & F1 & F2 & F3 & F4 & F5 & F6 & F7 \\
\hline A. flavus & 0 & $15.3 \pm 0.48^{\mathrm{a}}$ & 0 & 0 & $7.3 \pm 0.28^{c}$ & $8.3 \pm 0.28^{\mathrm{b}}$ & 0 & $7.2 \pm 0.76^{\mathbf{c}}$ & 0 \\
\hline A. niger & 0 & $8.5 \pm 0.36^{\mathrm{c}}$ & 0 & 0 & 0 & $7.7 \pm 1.15^{\mathbf{b}}$ & 0 & $8.0 \pm 1.73^{b}$ & $7.7 \pm 1.15^{b}$ \\
\hline A. ochraceus & 0 & $10.8 \pm 0.76^{\mathrm{a}}$ & 0 & 0 & 0 & $9.0 \pm 2.00^{\mathbf{b}}$ & $8.0 \pm 1.00^{\mathrm{c}}$ & $7.7 \pm 1.15^{\mathrm{c}}$ & $8.0 \pm 1.73^{\mathrm{c}}$ \\
\hline A. parasiticus & 0 & $11.8 \pm 1.04^{\mathbf{b}}$ & 0 & 0 & $7.3 \pm 0.28^{\mathbf{b}}$ & -- & $7.7 \pm 0.58^{b}$ & 0 & $8.0 \pm 1.00^{\mathbf{b}}$ \\
\hline A. westerdijikia & 0 & $10.8 \pm 0.86^{\mathrm{a}}$ & 0 & 0 & 0 & $9.0 \pm 1.00^{\mathbf{b}}$ & 0 & 0 & $8.3 \pm 0.58^{b}$ \\
\hline A. carbonarus & 0 & $10.6 \pm 0.36^{\mathrm{a}}$ & 0 & 0 & 0 & $9.3 \pm 1.52^{\mathbf{b}}$ & $8.0 \pm 1.00^{\mathrm{c}}$ & $7.7 \pm 1.15^{\mathrm{c}}$ & $8.0 \pm 1.73^{\mathrm{c}}$ \\
\hline F. verticelloides & 0 & $11.4 \pm 0.86^{\mathbf{a}}$ & 0 & 0 & $7.7 \pm 1.15^{\mathrm{c}}$ & $8.3 \pm 0.58^{\mathbf{b c}}$ & 0 & $7.3 \pm 0.58^{\mathrm{c}}$ & $9.0 \pm 1.00^{\mathbf{b}}$ \\
\hline F. proliferatum & 0 & $11.2 \pm 0.48^{\mathrm{a}}$ & 0 & 0 & $8.0 \pm 1.00^{\mathbf{b}}$ & $7.7 \pm 0.58^{b}$ & 0 & 0 & $7.3 \pm 0.58^{\mathrm{c}}$ \\
\hline P. verrucosum & 0 & $10.6 \pm 1.04^{\mathrm{a}}$ & 0 & 0 & $7.3 \pm 0.58^{\mathbf{b}}$ & 0 & 0 & 0 & $7.7 \pm 0.28^{b}$ \\
\hline
\end{tabular}

$\mathrm{n}=3$, *S.E: standard error, 0: No inhibition, -ve control: DMSO, +ve control: Nystatin, different superscripts within row are significantly different at the $5 \%$ level.

Shanab [51] reported that diethyl ether fractions of $O$. rubescens, O. humelli, and $O$. platensis exhibited great antibacterial activity against E. coli, B. subtilis, S. oblus, and S. faecalis. Madhumathi et al. [52] indicated that diethyl ether extract of O. latevirns had 
antibacterial activity against B. subtilis, E. coli, and S. mutans, while $S$. aureus and $K$. pneumonia were resistant. Katircioglu et al. [53] found that ether extract of Oscillatoria sp. had antimicrobial activity against B. subtilis, B. cereus, B. megaterium, E. coli, S. aureus, and P. aeruginosa. Ahmadi and Hosseini [54] also revealed that Oscillatoria sp. diethyl ether extract showed antibacterial activity against $E$. coli and B. subtilis. In contrast, Khairy and ElKassas [43] reported that $O$. angustissina diethyl ether extract had no antibacterial activity against B. subtilis, B. cereus, $S$. aureus, E. coli, and $P$. aeruginosa. Kim [55] reported that $O$. angustissima ether extract had antifungal activity against $F$. oxysporium and Alternaria alternata. Pawar and Puranik [56] indicated that $O$. ornata petroleum ether extract had antifungal activity against $A$. niger and $F$. oxysporum. In contrast, Shanab [38] found that diethyl ether fractions of $O$. rubescens, $O$. humelli and $O$. platensis showed no antifungal activity against $A$. flavus. Also, Padhi et al. [57] reported that $O$. princeps ether extract had no antifungal activity against $P$. notalum, $F$. moniliforme, and $A$. niger, while benzene extract had bioactivity against these fungi.

\subsection{Minimum inhibitory concentration (MIC) of O. princeps DEE and fractions.}

As shown in Fig. 2 and 3, the highest activity of $O$. princeps DEE was recorded against B. cereus, $S$. aureus, and $P$. aeruginosa with MIC value of $0.5 \mathrm{mg} \mathrm{ml}^{-1}$. Whereas the lowest activity was showed against $A$. ochraceus with MIC value of $1.8 \mathrm{mg} \mathrm{ml}^{-1}$. O. princeps $\mathrm{F} 4$ showed the highest activity against $A$. westerdijikia and $A$. carbonarus with MIC $0.8 \mathrm{mg} \mathrm{ml}^{-1}$, and the lowest activity was recorded against $B$. cereus and $P$. verrucosum with MIC $1.9 \mathrm{mg} \mathrm{ml}^{-}$ ${ }^{1}$. The highest activity of $\mathrm{F} 7$ with MIC value $0.7 \mathrm{mg} \mathrm{ml}^{-1}$ was showed against $P$. aeruginosa and $F$. verticelloides. At the same time, the lowest activity was recorded against $K$. pneumonia and $F$. proleferatum with MIC value of $1.6 \mathrm{mg} \mathrm{ml}^{-1}$.

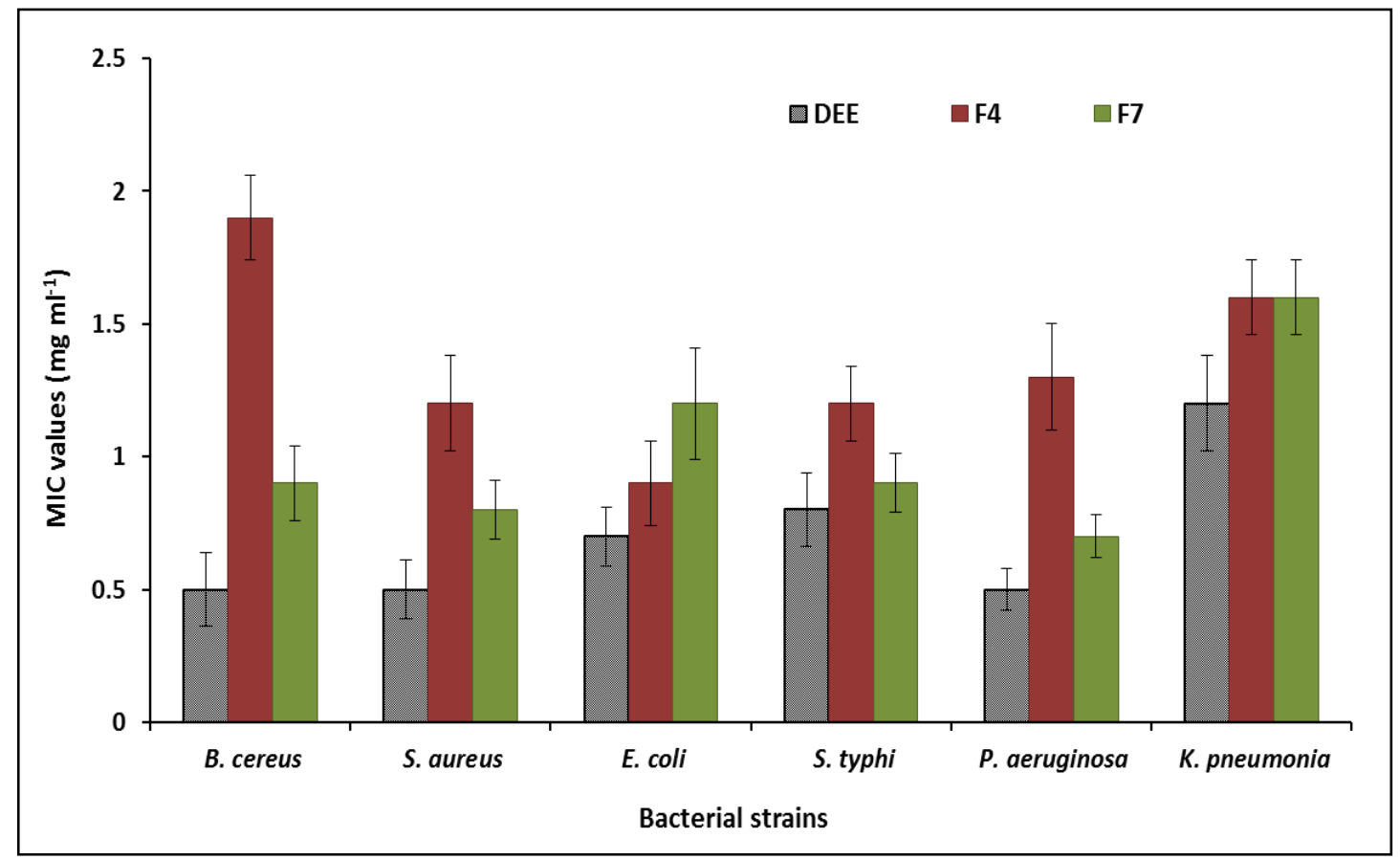

Figure 2. MIC values $\left(\mathrm{mg} \mathrm{ml}^{-1}\right)$ of $O$. princeps DEE and Fractions against pathogenic bacteria. 


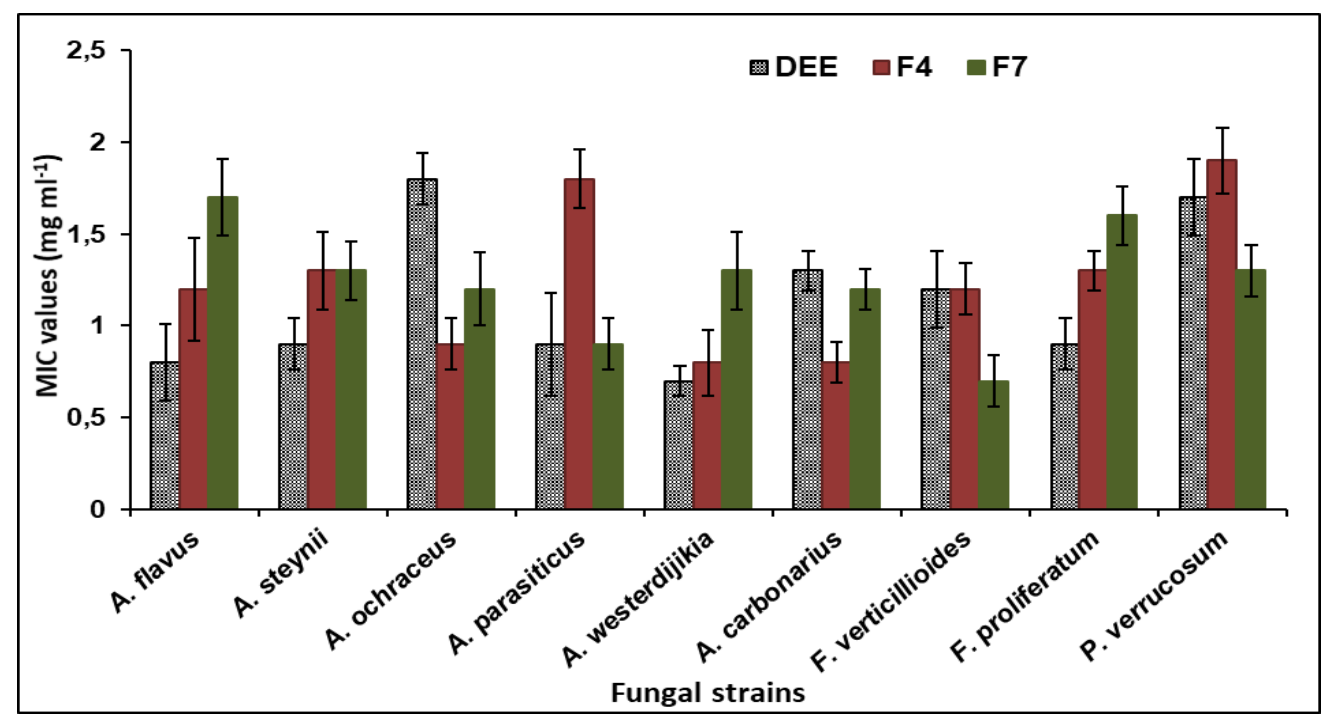

Figure 3. MIC values $\left(\mathrm{mg} \mathrm{ml}^{-1}\right)$ of $O$. princeps DEE and Fractions against toxigenic fungi.

Sethubathi and Prabu [58] reported that aqueous fraction from Oscillatoria sp. showed antibacterial activity against $S$. aureus, B. subtilis, P. aeruginosa, and K. pneumonia with MIC values ranged from 0.5 to $21.6 \mathrm{mg} \mathrm{ml}^{-1}$. Also, Al-Rekabi [59] found that $O$. amoena aqueous and ethanolic fractions had antibacterial activity against $S$. aureus, $P$. aeruginosa, B. subtilis, and $K$. pneumonia with MIC values in a range between 5 to $75 \mu \mathrm{g} \mathrm{ml}^{-1}$. They also reported that $O$. irrigua aqueous fraction had antifungal activity against $A$. flavus with MIC value of 1.25 $\mathrm{mg} \mathrm{ml^{-1 }}$.

\subsection{Cytotoxic activity of O. princeps DEE fractions.}

Since DEE fractions F4 and F7 of $O$. princeps had the highest activity as an antimicrobial agent against tested bacteria and fungi. These fractions were examined for their anticancer activity against HepG2, HCT116, and MCF7 cancer cell lines. The cytotoxicity of $O$. princeps fraction F4 is shown in Fig. 4. The highest anticancer activity was shown against HCT116 cells with IC 50 of $22.62 \mu \mathrm{g} \mathrm{ml}^{-1}$, followed by MCF7 cells with $\mathrm{IC}_{50}$ of $24.43 \mu \mathrm{g} \mathrm{ml}^{-1}$. While low anticancer activity was observed against HepG2 cell lines at IC50 of $102.52 \mu \mathrm{g} \mathrm{ml}^{-1}$.

The cytotoxicity of $O$. princeps fraction F7 is illustrated in Fig. 5. The highest anticancer activity was recorded against colon cancer cell lines HCT116 with IC50 of $30.82 \mu \mathrm{g}$ $\mathrm{ml}^{-1}$, followed by breast cancer cell lines MCF7 with $\mathrm{IC}_{50}$ of $39.73 \mu \mathrm{g} \mathrm{ml}^{-1}$. While No anticancer activity of $O$. princeps fraction F7 was showed against liver cancer cell lines HepG2 by using concentrations reach $10 \mathrm{mg} \mathrm{ml}^{-1}$.

Roussis et al. [60] reported that the lipophilic fractions of O. acutissima had shown anticancer activity against colon cancer cell lines HCT116 and breast cancer cell lines MCF7 with $\mathrm{IC}_{50}$ of 9.5 and $6.0 \mu \mathrm{g} \mathrm{mg}^{-1}$, respectively. Shanab et al. [47] found that major secondary metabolites of Oscillatoria sp., total phenolic content, terpenoids, and alkaloids as well as phycobiliprotein pigments, phycocyanin, allophycocyanin, and phycoerythrin were showed to have anticancer activity against Ehrlich ascites carcinoma cell (EACC) and Human hepatocellular cancer cell line (HepG2). Also, Nair and Bhimba [49] indicated that the crude extract of Oscillatoria boryana possessed anticancer activity against the breast cancer cell lines MCF7. Marrez et al. [19] revealed that Oscillatoria brevis diethyl ether fraction F4 showed high anticancer activity against MCF7 and HCT116 cell lines with IC 50 values of 20.6 and 23.4 $\mu \mathrm{g} \mathrm{mg}^{-1}$, respectively. 


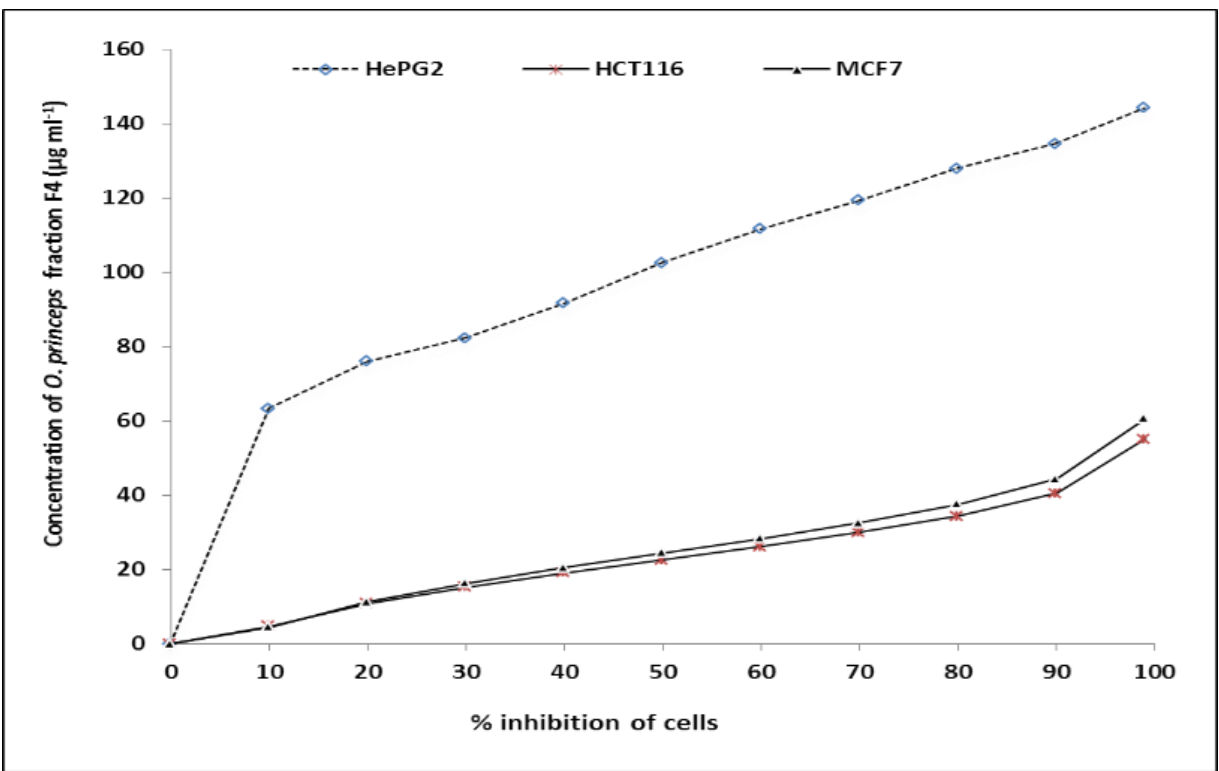

Figure 4. Cytotoxic assay of $O$. princeps diethyl ether extract F4 on HePG2, HCT116, and MCF7 cell lines.

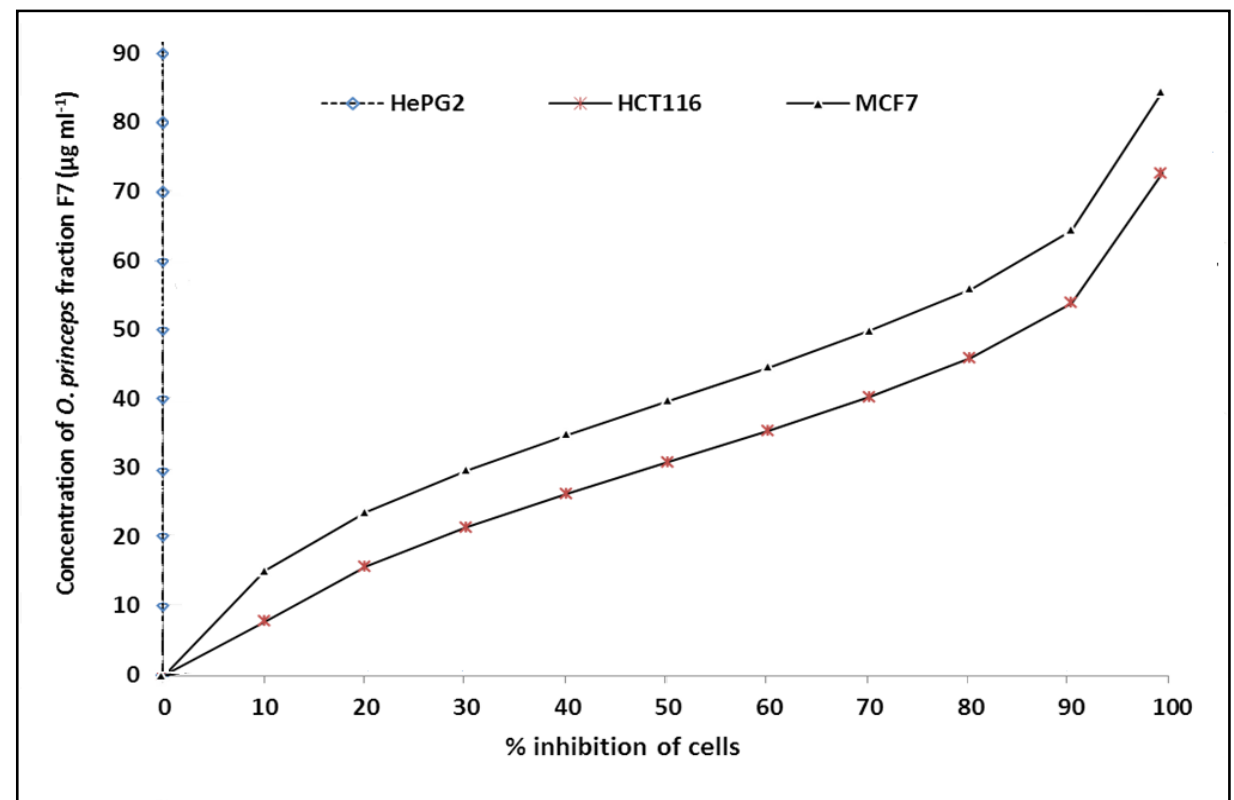

Figure 5. Cytotoxic assay of $O$. princeps diethyl ether extract F7 on HePG2, HCT116, and MCF7 cell lines.

\subsection{Identification of O. princeps bioactive fractions using $G C-M S$.}

Totally 10 compounds were identified by GC-MS from $O$. princeps fraction F4. These compounds were 9,12-Octadecadienoic acid (Z,Z)- with peak area percent $8.62 \%$, 9Octadecenoic acid (15.82\%), N-2,4-Dnp-L-arginine (5.34\%), Hexadecanoic acid (8.92\%), Pentadeconic acid,4 hexadecyl ester (27.26\%), 9,15-Octadecadienoic acid, methyl ester (7.66\%), 11-Octadecenoic acid, methyl ester (10.65\%), Ethyl iso-allocholate (1.77\%), Dimethoxyglycerol docosyl ether (11.58) and Stearic acid 4.07\% (Fig. 6 and Table 5).

Surendhiran et al. [61] reported that the fatty acids Hexadecanoic acid, 9-Octadecenoic acid, and 9,12-Octadecadienoic acid, which isolated from microalgae Nannochloropsis oculata showed antibacterial activity against $P$. aeruginosa, E. coli, B. subtilis, and S. aureus. Also, Khalid and Shameel [62] found that fatty acids 9,12-Octadecadienoic acid and 9-Octadecenoic acid from methanol extract of green alga Spirogyra rhizoides showed antimicrobial activity against B. cereus, E. coli, P. aeruginosa, K. pneumonia, S. typhi, S. faecalis, S. pyogenes, $V$. choleriae, F. oxysporum, and A. flavus. Marimuthu et al. [63] indicated that the fatty acids 
Hexadecanoic acid methyl ester, 9-Octadecenoic acid, 9,12-Octadecadienoic acid (Z,Z), 11Octadecenoic acid methyl ester, and Ethyl iso-allocholate, which extracted from dry Christmas lima bean, had antimicrobial activity against E. coli, S. aureus, A. flavus, and A. niger. They also reported that 9-Octadecenoic acid was found to be effective against fungi A.flavus. Also, Asghar et al. [64] indicated that the bioactive fractions 9-Octadecenoic acid methyl ester and 11-Octadecenoic acid methyl ester from ether extract of Iris plants showed antimicrobial activity against E. coli, B. subtilis, S. aureus, A. flavus, and A. niger.

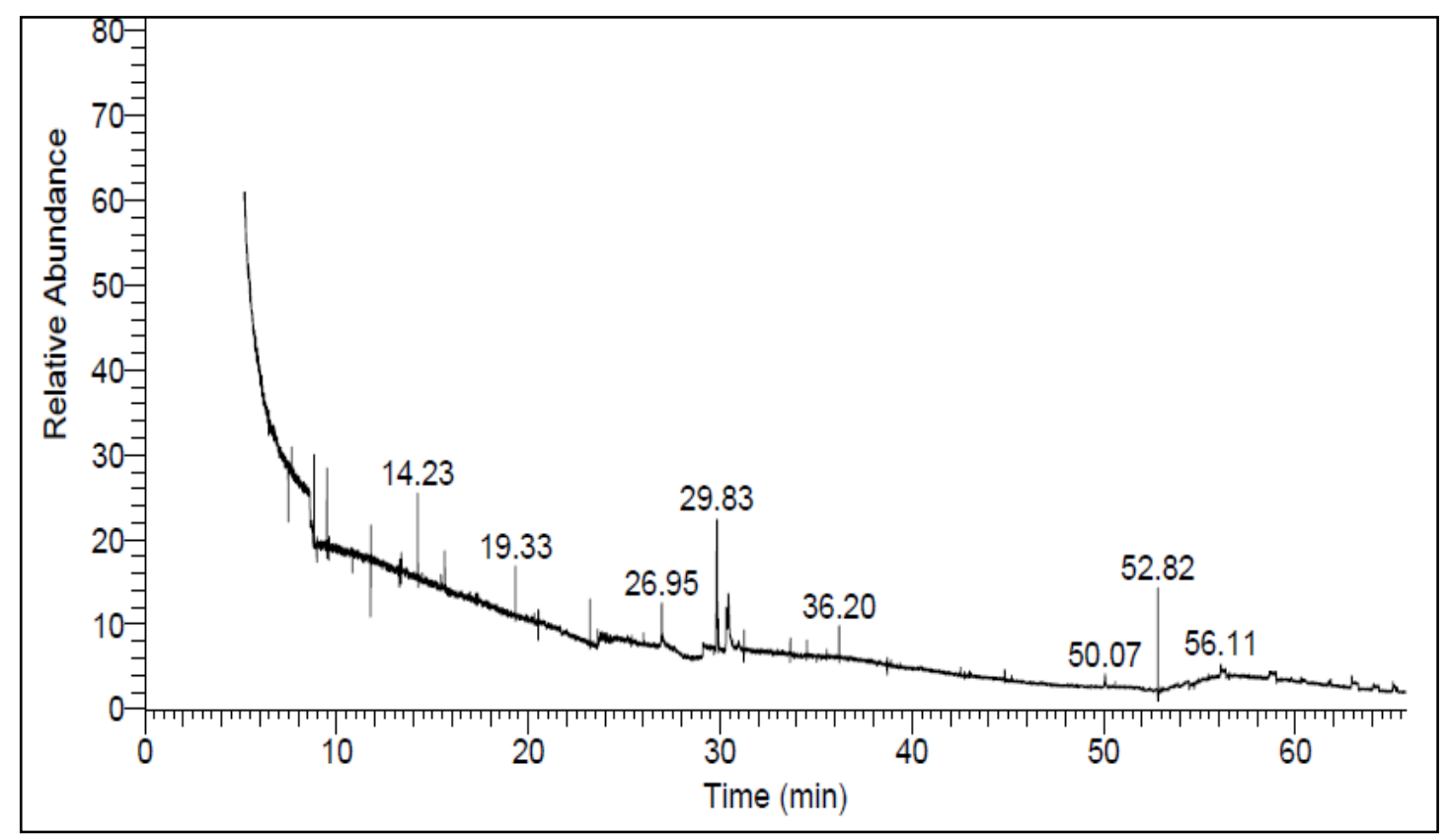

Figure 6. GC-MS chromatogram of $O$. princeps DEE extract fraction F4.

Table 5. Components detected in fraction F4 of $O$. princeps DEE extract.

\begin{tabular}{|c|c|c|c|c|c|}
\hline No & RT & Compound & Area \% & Molecular formula & MW \\
\hline 1 & 10.45 & 9,12-Octadecadienoic acid (Z,Z)- & 8.62 & $\mathrm{C}_{18} \mathrm{H}_{32} \mathrm{O}_{2}$ & 280 \\
\hline 2 & 14.23 & 9-Octadecenoic acid & 15.82 & $\mathrm{C}_{18} \mathrm{H}_{34} \mathrm{O}_{2}$ & 282 \\
\hline 3 & 19.33 & N-2,4-Dnp-L-arginine & 5.34 & $\mathrm{C}_{12} \mathrm{H}_{16} \mathrm{~N}_{6} \mathrm{O}_{6}$ & 340 \\
\hline 4 & 26.95 & Hexadecanoic acid & 8.92 & $\mathrm{C}_{16} \mathrm{H}_{32} \mathrm{O}_{2}$ & 256 \\
\hline 5 & 29.83 & Pentadeconic acid,4- hexadecyl ester & 27.26 & $\mathrm{C}_{15} \mathrm{H}_{30} \mathrm{O}_{2}$ & 242 \\
\hline 6 & 30.33 & 9,15-Octadecadienoic acid, methyl ester & 7.66 & $\mathrm{C}_{19} \mathrm{H}_{34} \mathrm{O}_{2}$ & 294 \\
\hline 7 & 36.20 & 11-Octadecenoic acid, methyl ester & 10.65 & $\mathrm{C}_{19} \mathrm{H}_{36} \mathrm{O}_{2}$ & 296 \\
\hline 8 & 50.07 & Ethyl iso-allocholate & 1.77 & $\mathrm{C}_{26} \mathrm{H}_{44} \mathrm{O}_{5}$ & 436 \\
\hline 9 & 52.82 & Dimethoxyglycerol docosyl ether & 11.58 & $\mathrm{C}_{27} \mathrm{H}_{56} \mathrm{O}_{5}$ & 460 \\
\hline 10 & 56.11 & Stearic acid & 4.07 & $\mathrm{C}_{39} \mathrm{H}_{78} \mathrm{O}_{3}$ & 594 \\
\hline
\end{tabular}

The results about GC-MS analysis of $O$. princeps fraction F7 are illustrated in Fig. 7 and Table 6. It revealed the presence of 5 metabolites with retention time ranging from 17.52 to $63.63 \mathrm{~min}$. The maximum peak was identified as Methyl tetradecanoate (Myristic acid, methyl ester) $64.10 \%$, followed by Quercetin 7,3',4'-trimethoxy $13.48 \%$ and Octasiloxane $9.85 \%$. While, the minimum peak was identified as Cis-vaccenic acid $2.42 \%$, followed by $9,12-$ Octadecadienoic acid (Z,Z) 3.577 and Heptasiloxane 5.94\%.

Ahmad et al. [65] revealed that 9-Octadecenoic acid and 9,15-Octadecadienoic acid methyl ester from the lipid extract of medicinal plant Acacia modesta had antifungal activity against $A$. flavus and $F$. solani as well as cytotoxic activity against Artemia salina. While, the lipid fractions were inactive against E. coli, B. subtilis, S. aureus, P. aeruginosa, and S. typhi. Sheela and Uthayakumari [66] indicated that Ethyl iso-allocholate, 9-Octadecenoic acid, and Hexadecanoic acid from ethanolic extract of costal plant Sesuvium portulacastrum had 
antimicrobial, anticancer, and antioxidant activities. Rajalakashmi and Mahesh [67] reported that bioactive metabolites Octasiloxane, 9,12-Octadecadienoic acid (Z,Z) and Heptasiloxane, which extracted from $A$. terrus in rhizosphere soil of medicinal plants, had antibacterial activity against K. pneumonia, E. coli, B. subtilis, S. aureus, and P. aeruginosa. Salem et al. [68] reported that Quercetin 7,3',4'-trimethoxy from Nostoc sp. methanol extract had antimicrobial activity against B. subtilis, $K$. pneumoniae, S. aureus, and A. niger. Also, Marrez et al. [8] found that 9-Octadecenoic acid, Quercetin 7,3',4'-trimethoxy, and Octasiloxane isolated from S. obliquus diethyl ether fractions had antibacterial activity against B. cereus, Staph. aureus, E. coli, P. aeruginosa, S. typhi, K. pneumonia and antifungal activity against A. flavus, $A$. steynii, A. ochraceus, A. parasiticus, A. westerdijikia, A. carbonarius, $F$. verticillioides, $F$. proliferatum, and $P$. verrucosum.

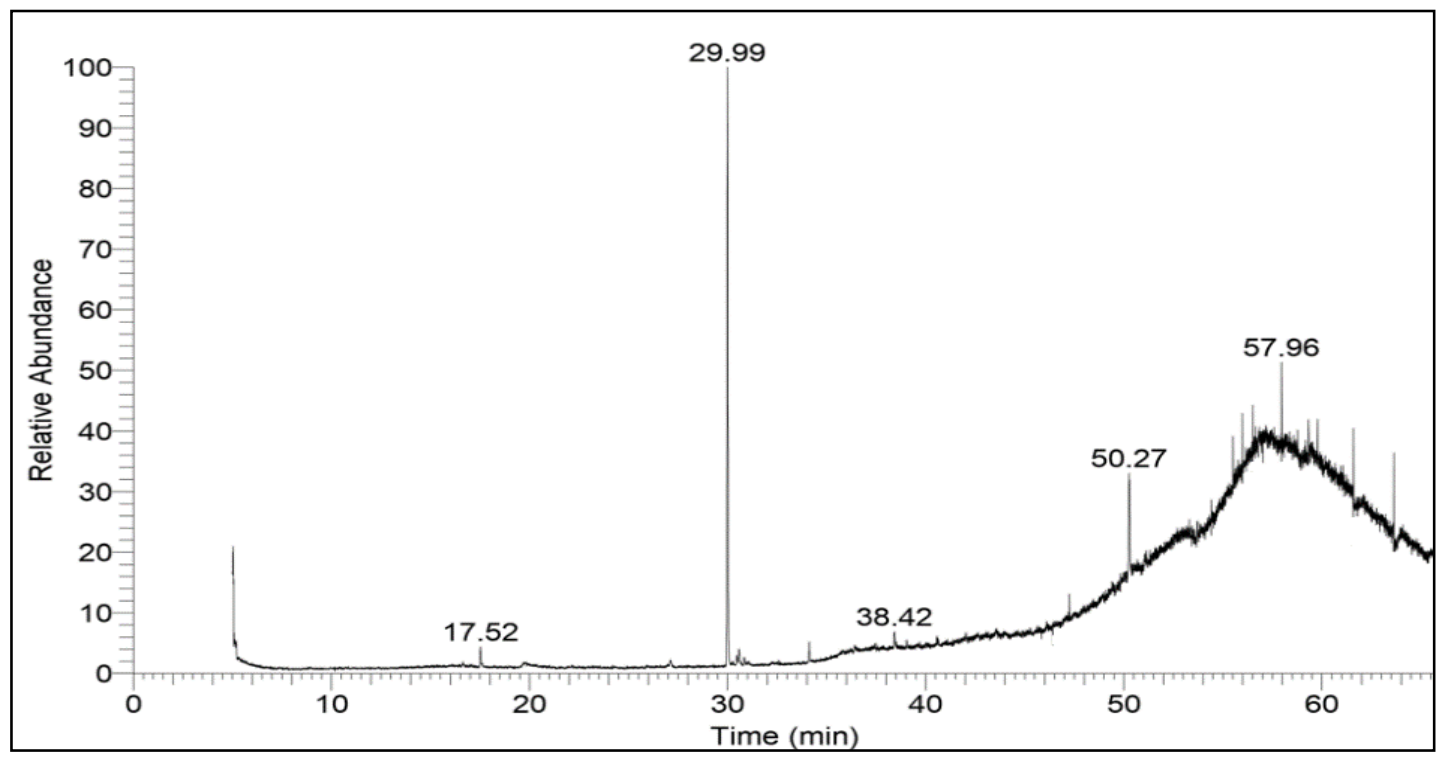

Figure 7. GC-MS chromatogram of $O$. princeps DEE extract fraction F7.

Table 6. Components detected in fraction F7 of $O$. princeps DEE extract.

\begin{tabular}{c|c|l|c|c|c}
\hline No & RT & Compound & Area \% & Molecular formula & MW \\
\hline $\mathbf{1}$ & 17.52 & $9,12-$-Octadecadienoic acid (Z,Z)- & 3.57 & $\mathrm{C}_{18} \mathrm{H}_{32} \mathrm{O}_{2}$ & 280 \\
\hline $\mathbf{2}$ & 29.99 & Methyl tetradecanoate (Myristic acid, methyl ester) & 64.10 & $\mathrm{C}_{15} \mathrm{H}_{30} \mathrm{O}_{2}$ & 242 \\
\hline $\mathbf{3}$ & 30.57 & Cis-vaccenic acid & 2.42 & $\mathrm{C}_{18} \mathrm{H}_{34} \mathrm{O}_{2}$ & 282 \\
\hline $\mathbf{4}$ & 50.27 & Quercetin 7,3',4'-trimethoxy & 13.48 & $\mathrm{C}_{18} \mathrm{H}_{16} \mathrm{O}_{7}$ & 344 \\
\hline $\mathbf{5}$ & 57.96 & Octasiloxane & 9.85 & $\mathrm{C}_{16} \mathrm{H}_{50} \mathrm{O}_{7} \mathrm{Si}_{8}$ & 578 \\
\hline $\mathbf{6}$ & 63.63 & Heptasiloxane & 5.94 & $\mathrm{C}_{14} \mathrm{H}_{44} \mathrm{O}_{6} \mathrm{Si}_{7}$ & 504 \\
\hline
\end{tabular}

Udgire and Pathade [69] reported that Pentadeconic acid, 4- hexadecyl ester, isolated from the medicinal plant Valeriana wallichii showed had antimicrobial activity against $K$. pneumonia, E. coli, S. aureus, P. aeruginosa, and A. niger. Hamlal and Subban [70] found that Cis-vaccenic acid, 9,12-Octadecadienoic acid, and 11-Octadecenoic acid, methyl ester from methanolic extract of $P$. viscida and $D$. gangeticum dried roots possessed antimicrobial activity against B. cereus, S. aureus, A. flavus, A. terrus, and P. notatum. Laungsuwon and Chulalaksananukul [71] indicated that Methyl tetradecanoate (Myristic acid, methyl ester) extracted from microalgae $C$. glomerata and $M$. floccosa showed antibacterial activity against B. cereus and S. aureus. Marrez and Sultan [72] revealed that 9,12-Octadecadienoic acid and Pentadeconic acid,4 hexadecyl ester which isolated from Microcystis aeruginosa diethyl ether sub-fraction F4-10 had antifungal activity against A. flavus, A. niger, A. ochraceus, A. parasiticus, A. westerdijikia, A. carbonarius, $F$. proliferatum, $F$. verticillioides, and $P$. verrucosum. Abdel-Rahman et al. [73] found that 9-Octadecenoic acid, Octasiloxane, and 9,12- 
Octadecadienoic acid from Microcystis aeruginosa diethyl ether fraction F7 showed antibacterial activity against $B$. cereus, S. aureus, E. coli, P. aeruginosa, S. typhi, K. pneumonia, and anticancer activity HCT116 cell line.

\section{Conclusions}

The current study demonstrated that $O$. princeps a rich source of bioactive compounds with antimicrobial activity wide range of foodborne pathogenic bacteria and mycotoxigenic fungi. Furthermore, these extracts exhibited anticancer activity against HePG2, HTC116, and MCF7 cell lines. Also, O. princeps DEE fraction showed bioactivity against pathogenic microorganisms and cancer cell lines which qualifies it to be a safe and cheap source for pharmaceutical and food bio-preservative ingredients.

\section{Funding}

This research received no external funding.

\section{Acknowledgments}

This research has no acknowledgment.

\section{Conflicts of Interest}

The authors declare no conflict of interest.

\section{References}

1. Firáková, S.; Šturdíková, M.; Múčková, M. Bioactive secondary metabolites produced by microorganisms associated with plants. Biologia 2007, 62, 251-257, https://doi.org/10.2478/s11756-007-0044-1.

2. Abdel-Rahman, G.N.-E.; Ahmed, M.B.M.; Marrez, D.A. Reduction of Heavy Metals Content in Contaminated Vegetables due to the Post-harvest Treatments. Egyptian J. Chem 2018, 61, 1031-1037, https://doi.org/10.21608/ejchem.2018.3624.1303.

3. Amer, H.M.; Marrez, D.A.; Salama, A.B.; Wahba, H.E.; Khalid, K.A. Growth and chemical constituents of cardoon plant in response to foliar application of various algal extracts. Biocatal. .Agric. Biotechnol., 2019, 21, https://doi.org/10.1016/j.bcab.2019.101336.

4. Hamad, M.; Marrez, D.; El-Sherbieny S. Toxicity evaluation and antimicrobial activity of purified pyocyanin from Pseudomonas aeruginosa. Biointerface Res Appl Chem 2020, 10, 6974-6990, https://doi.org/10.33263/BRIAC106.69746990

5. Shallan, M.; Ali, M.; Meshrf, W.; Marrez, D. In vitro antimicrobial, antioxidant and anticancer activities of globe artichoke (Cynara cardunculus var. scolymus L.) bracts and receptacles ethanolic extract. Biocatal. Agric. Biotechnol., 2020, 29, 101774, https://doi.org/10.1016/j.bcab.2020.101774

6. Zahra, Z.; Choo, D.H.; Lee, H.; Parveen, A. Cyanobacteria: Review of Current Potentials and Applications. Environments 2020, 7, 1-17, https://doi.org/10.3390/environments7020013.

7. Marrez, D.; Naguib, M.M.; Sultan, Y.; Daw, Z.Y.; Higazy, A.M. Evaluation of chemical composition for Spirulina platensis in different culture media. Research Journal of Pharmaceutical, Biological and Chemical Sciences 2014, 5, 1161-1171.

8. Marrez, D.A.; Naguib, M.M.; Sultan, Y.Y.; Higazy, A.M. Antimicrobial and anticancer activities of Scenedesmus obliquus metabolites. Heliyon 2019, 5, https://doi.org/10.1016/j.heliyon.2019.e01404.

9. Farrokh, P.; Sheikhpour, M.; Kasaeian, A.; Asadi, H.; Bavandi, R. Cyanobacteria as an eco-friendly resource for biofuel production: A critical review. Biotechnol Prog 2019, 35, https://doi.org/10.1002/btpr.2835.

10. Lasry Testa, R.; Delpino, C.; Estrada, V.; Diaz, S.M. In silico strategies to couple production of bioethanol with growth in cyanobacteria. Biotechnology and Bioengineering 2019, 116, 2061-2073, https://doi.org/10.1002/bit.26998.

11. Yasin, D.; Zafaryab, M.; Ansari, S.; Ahmad, N.; Khan, N.F.; Zaki, A.; Alam Rizvi, M.M.; Fatma, T. Evaluation of antioxidant and anti-proliferative efficacy of Nostoc muscorum NCCU-442. Biocatalysis and Agricultural Biotechnology 2019, 17, 284-293, https://doi.org/10.1016/j.bcab.2018.12.001. 
12. Lau, N.-S.; Matsui, M.; Abdullah, A.A.-A. Cyanobacteria: Photoautotrophic Microbial Factories for the Sustainable Synthesis of Industrial Products. BioMed Research International 2015, 2015, https://doi.org/10.1155/2015/754934.

13. Meireles dos Santos, A.; Vieira, K.R.; Basso Sartori, R.; Meireles dos Santos, A.; Queiroz, M.I.; Queiroz Zepka, L.; Jacob-Lopes, E. Heterotrophic Cultivation of Cyanobacteria: Study of Effect of Exogenous Sources of Organic Carbon, Absolute Amount of Nutrients, and Stirring Speed on Biomass and Lipid Productivity. Frontiers in Bioengineering and Biotechnology 2017, 5, 1-7, https://doi.org/10.3389/fbioe.2017.00012.

14. Tiwari, A.K.; Tiwari, B.S. Cyanotherapeutics: an emerging field for future drug discovery. Applied Phycology 2020, 1, 44-57, https://doi.org/10.1080/26388081.2020.1744480.

15. Rojas, V.; Rivas, L.; Cárdenas, C.; Guzmán, F. Cyanobacteria and Eukaryotic Microalgae as Emerging Sources of Antibacterial Peptides. Molecules 2020, 25, https://doi.org/10.3390/molecules25245804.

16. Kini, S.; Divyashree, M.; Mani, M.K.; Mamatha, B.S. Chapter 12 - Algae and cyanobacteria as a source of novel bioactive compounds for biomedical applications. In: Advances in Cyanobacterial Biology. Singh, P.K.; Kumar, A.; Singh, V.K.; Shrivastava, A.K. Eds. Academic Press: 2020; pp. 173-194, https://doi.org/10.1016/B978-0-12-819311-2.00012-7.

17. Chronakis, I. Biosolar protein from aquatic algae, In: Novel Macromolecules in Food Systems. Eds. Doxastakis, G.; Kiosseoglou, V. Center for Chemistry and Chemical Engineering, Lund, Sweden, 2000; pp. 39-75.

18. Gale, G.A.R.; Schiavon Osorio, A.A.; Mills, L.A.; Wang, B.; Lea-Smith, D.J.; McCormick, A.J. Emerging Species and Genome Editing Tools: Future Prospects in Cyanobacterial Synthetic Biology. Microorganisms 2019, 7, https://doi.org/10.3390/microorganisms7100409.

19. Marrez, D.; Sultan, Y.; Embays, M. Biological activity of the cyanobacterium Oscillatoria brevis extracts as a source of nutraceutical and bio-preservative agents. Int. J. Pharmacol. 2017, 13, 1010-1019, https://doi.org/10.3923/ijp.2017.1010.1019.

20. Levasseur, W.; Perré, P.; Pozzobon, V. A review of high value-added molecules production by microalgae in light of the classification. Biotechnol. Adv. 2020, 41, https://doi.org/10.1016/j.biotechadv.2020.107545.

21. Galasso, C.; Gentile, A.; Orefice, I.; Ianora, A.; Bruno, A.; Noonan, D.; Sansone, C.; Albini, A.; Brunet, C. Microalgal Derivatives as Potential Nutraceutical and Food Supplements for Human Health: A Focus on Cancer Prevention and Interception. Nutrients 2019, 110, https://doi.org/10.3390/nu11061226.

22. Sultan, Y.; Ali, M.; Darwesh, O.; Embaby, M.; Marrez, D. Influence of nitrogen source in culture media on antimicrobial activity of Microcoleus lacustris and Oscillatoria rubescens. Res. J. Pharm. Biol. Chem. Sci. 2016, 7, 1444-1452.

23. Demay, J.; Bernard, C.; Reinhardt, A.; Marie, B. Natural Products from Cyanobacteria: Focus on Beneficial Activities. Marine Drugs 2019, 17, https://doi.org/10.3390/md17060320.

24. Mohamed, R.S.; Marrez, D.A.; Salem, S.H.; Zaghloul, A.H.; Ashoush, I.S.; Farrag, A.R.H.; Abdel-Salam, A.M. Hypoglycemic, hypolipidemic and antioxidant effects of green sprouts juice and functional dairy micronutrients against streptozotocin-induced oxidative stress and diabetes in rats. Heliyon 2019, 5, https://doi.org/10.1016/j.heliyon.2019.e01197.

25. Niccolai, A.; Chini Zittelli, G.; Rodolfi, L.; Biondi, N.; Tredici, M.R. Microalgae of interest as food source: Biochemical composition and digestibility. Algal Research 2019, 42, https://doi.org/10.1016/j.algal.2019.101617.

26. Nwoba, E.G.; Ogbonna, C.N.; Ishika, T.; Vadiveloo, A. Microalgal Pigments: A Source of Natural Food Colors. In: Microalgae Biotechnology for Food, Health and High Value Products. Alam, M.A.; Xu, J.-L.; Wang, Z. Eds. Springer Singapore: Singapore, 2020; pp. 81-123, https://doi.org/10.1007/978-981-15-0169$2 \_3$.

27. Mu, N.; Mehar, J.; Mudliar, S.; Shekh, A. Recent Advances in Microalgal Bioactives for Food, Feed, and Healthcare Products: Commercial Potential, Market Space, and Sustainability. Comprehensive Reviews in Food Science and Food Safety 2019, 18, 1882-1897, https://doi.org/10.1111/1541-4337.12500.

28. Marrez, D.A.; Mohamed M.N.; Sultan, Y.Y.; Daw, Z.Y.; Zaher, S.S.; Higazy, A.M. Phytoplankton profile and toxicity assessment of dominant algal species from different Egyptian aquatic ecosystems. Res. J. Pharm. Biol. Chem. Sci 2016, 7, 1453-1461.

29. Rippka, R.; Deruelles, J.; Waterbury, B.; Herdman, M.; Stanier, Y. Generic assignments, strain histories and properties of pure cultures of cyanobacteria. J. Gen. Microb. 1979, 111, 1-61, https://doi.org/10.1099/00221287-111-1-1.

30. Marrez, D.; Abdel-Rahman, G.; Salem, S. Evaluation of Pseudomonas fluorescens Extracts as Biocontrol Agents Against some Foodborne Microorganisms. Jordan J. Biol. Sci. 2019, 12, 535-541.

31. Bauer, A.; Kirby, W.; Sheriss, J.; Turck, M. Antibiotic susceptibility testing by standardized single method. Am. J. Clin. Pathol. 1996, 45, 493-496, https://doi.org/10.1093/ajcp/45.4_ts.493.

32. Marrez, D.A.; El Raey, M.A.; El-Hagrassi, A.M.; Seif, M.M.; Ragab, T.M.; El Negoumy, S.I.; Emam M. Phenolic profile and antimicrobial activity of green synthesized Acalypha wilkesiana seed's silver nanoparticles against some food borne pathogens. Bioscience Research 2017, 14, 817-830. 
33. Embaby, M.; El-Raey, M.; Zaineldain, M.; Almaghrabi, O.; Marrez, D. Synergistic effect and efflux pump inhibitory activity of Ficus nitida phenolic extract with tetracycline against some pathogenic bacteria. Toxin Rev. 2019, 39, https://doi.org/10.1080/15569543.2019.1659370.

34. Medeiros, M.; Oliveira, D.; Rodrigues, D.; Freitas, D. Prevalence and antimicrobial resistance of Salmonella in chicken carcasses at retail in 15 Brazilian cities. Rev. Panam. Salud. Public. 2011, 30, 555-560, https://doi.org/10.1590/s1020-49892011001200010.

35. Andrews, J.M. Determination of minimum inhibitory concentrations. Journal of Antimicrobial Chemotherapy 2001, 48, 5-16, https://doi.org/10.1093/jac/48.suppl_1.5.

36. Sokmen, A.; Gulluce, M.; Askin Akpulat, H.; Daferera, D.; Tepe, B.; Polissiou, M.; Sokmen, M.; Sahin, F. The in vitro antimicrobial and antioxidant activities of the essential oils and methanol extracts of endemic Thymus spathulifolius. Food Control 2004, 15, 627-634, https://doi.org/10.1016/j.foodcont.2003.10.005.

37. Mosmann, T. Rapid colorimetric assay for cellular growth and survival: Application to proliferation and cytotoxicity assays. Journal of Immunological Methods 1983, 65, 55-63, https://doi.org/10.1016/00221759(83)90303-4.

38. Krishnamurthy, M.; V, R.; Rajaram, R. Antimicrobial activity of Oscillatoria princeps and Lyngbya majuscule against pathogenic microbes. International journal of current research 2010, 5, 097-101.

39. Al-Rubaiee, G.; Shaukat, D. Influence the effectiveness of compounds produced from algae Oscllatoria princeps against bacteria and detected of some fatty acids. Iraq J. Sci. 2013, 54, 266-273.

40. Rath, B.; Priyadarshani, I. Antibacterial and antifungal activity of marine cyanobacteria from Odisha Coast. Int. J. Cur. Tr. Res. 2013, 2, 248-251.

41. Abd El-Aty, A.; Amin Mohamed, A.; Samhan, F. In vitro antioxidant and antibacterial activities of two fresh water Cyanobacterial species, Oscillatoria agardhii and Anabaena sphaerica. Journal of Applied Pharmaceutical Science 2014, 4, 69-75.

42. Selim, E.; Barakat, O.; Aly, M.; Higazy, A. Ecological evaluation of marine cyanobacteria of El-Khadra lake in Egypt. Int. J. Curr. Microbiol. Appl. Sci. 2014, 3, 468-485.

43. Khairy, H.; El-Kassas, Y. Active substance from some blue green algal species used as antimicrobial agents. Afr. J. Biotechnol. 2010, 9, 2789-2800.

44. Haggag, W.; Abd El-Aty, A.; Mohamed, A. The potential effect of two cyanobacterial species; Anabaena sphaerica and Oscillatoria agardhii against grain storage fungi. Eur. Sci. J. 2014, 10, 427-443.

45. Rajendran, N.; Selvan, B.; Piriya, P.; Logeswari, V.; Kathiresan, E.; Tamilselvi, A.; Vennison, S. Phytochemicals, antimicrobial and antioxidant screening from five different marine microalgae. J. Chem. Pharm. Sci. 2014, 2, 78-85.

46. Mevers, E.; Liu, W.; Engene, N.; Mohimani, H.; Byrum, T.; Pevzner, P. Cytotoxic veraguamides, alkynyl bromide-containing cyclic depsipeptides from the marine cyanobacterium Oscillatoria margaritifera. J. Nat. Prod. 2011, 74, 928-936, https://doi.org/10.1021/np200077f.

47. Shanab, S.; Mostafa, S.; Shalaby, E.; Ibrahim, G. Aqueous extracts of microalgae exhibit antioxidant and anticancer activities. Asian Pac. J. Trop. Biomed. 2012, 2, 608-615, https://doi.org/10.1016/S22211691(12)60106-3.

48. Maruthanayagam, V.; Nagarajan, M.; Sundararaman, M. Cytotoxicity assessment of cultivable marine cyanobacterial extracts in Artemia salina (brine shrimp) larvae and cancer cell lines. Toxin Rev., 2013, 32, 1-9. https://doi.org/10.3109/15569543.2012.754772.

49. Nair, S.; Bhimba, V. Bioactive potency of cyanobacteria Oscillatoria SPP. International Journal of Pharmacy and Pharmaceutical Sciences 2013, 5, 611-612.

50. Mukund, S.; Sivasubramanian, V.; Senthilkumar, N. In-silico studies on metabolites of Phormidium fragile against colon cancer EGFR protein. J. Algal Biomass Utln. 2014, 5, 16-22.

51. Shanab, S. Bioactive allelo-chemical compounds from Oscillatoria Species (Egyptian Isolates). Int. J. Agric. Biol. 2007, 9, 617-621.

52. Madhumathi, V.; Deepa, P.; Jeyachandran, S.; Manoharan, C.; Vijayakumar, S. Antimicrobial Activity of Cyanobacteria Isolated from Freshwater Lake. Int J Microbiol Res 2011, 2, 213-216.

53. Katircioglu, H.; Beyatli, B.; Aslim, Z. and Yuksekdag, T. Screening for antimicrobial agent production in fresh water. Int. J. Microbiol. 2006, 2, 1-9.

54. Ahmadi, M.; Hosseini, F. Antimicrobial activity of cyanobacteria isolated from Shahid Rajaee hydrothermal freshwater fish pool in the city of Sari. Cibtech J. Zool. 2014, 3, 64-67.

55. Kim, J. Screening of cyanobacteria (blue-green algae) from rice paddy soil for antifungal activity against plant pathogenic fungi. Mycobiol. 2006, 34, 138-142.

56. Pawar, S.; Puranik, P. Screening of terrestrial and freshwater Halotolerant cyanobacteria for antifungal activities. World J. Microbiol. Biotechnol. 2008, 24,1019-1025,https://doi.org/10.1007/s11274-007-9565-6.

57. Padhi, S.; Samantaray, S.; Swain, P. Cyanobacteria, its antimicrobial activity and carbon sequestration capability. Discovery 2014, 24, 146-151.

58. Sethubathi, G.; Prabu, V. Antibacterial activity of cyanobacterial species from Adirampattinam coast, southeast coast of Palk Bay. Curr. Res. J. Biol. Sci. 2010, 2, 24-26.

59. Al-Rekabi, H. Study the effect of some algae extracts against activity of some fungi. J. Thi-Qar Univ. 2011, 4, 35-42. 
60. Roussis, V.; Vagias, C.; Tziveleka, L. Cytotoxic metabolites marine algae. In: Plant Fight Cancer. Eds. Kintzios, S.; Barberaki, M. CRC Press, Washington, D.C, USA, 2004; pp. 196-296.

61. Surendhiran, D.; Vijay, M.; Sirajunnisa, A.; Subramaniyan, T.; Shellomith, A.; Tamilselvam, K. A green synthesis of antimicrobial compounds from marine microalgae Nannochloropsis oculata. J. Coastal Life Med. 2014, 2, 859-863.

62. Khalid, M.; Shameel, M. Studies on the phycochemistry and biological activity of Spirogyra rhizoides (Chlorophycota). Pak. J. Bot. 2012, 44, 1815-1820.

63. Marimuthu, M.; Nagara, N.; Ravi, D. GC-MS analysis of phytochemicals, fatty acids and antimicrobial potency of dry Christmas lima beans. Int. J. Pharm. Sci. Rev. Res. 2014, 27, 63-66.

64. Asghar, S.; Rehman, H.; Choudahry, M.; Rahman, A. Gas chromatography-mass spectrometry (GC-MS) analysis of petroleum ether extract (oil) and bioassays of crude extract of Iris germanica. Int. J. Gen. Mol. Biol. 2011, 3, 95-100.

65. Ahmad, B.; Khan, I.; Bashir, S.; Azam, S. Chemical composition and antifungal, phytotoxic, brine shrimp cytotoxicity, insecticidal and antibacterial activities of the essential oils of Acacia modesta. J. Med. Plants Res. 2012, 6, 4653-4659.

66. Sheela, D.; Uthayakumari, F. GC-MS analysis of bioactive constituents from coastal sand dune taxon sesuvium portulacastrum (L.). Biosci. Discov. 2013, 4, 47-53.

67. Rajalakshmi, S.; Mahesh, N. Production and characterization of bioactive metabolites isolated from Aspergillus terreus in Rhizosphere soil of medicinal plants. Int. J. Curr. Microbiol. Appl. Sci. 2014, 3, 784798.

68. Salem, O.; Hoballah, E.; Ghazi, S.; Hanna, S. Antimicrobial activity of microalgal extracts with special emphasize on Nostoc sp. Life Sci. J. 2014, 11, 752-758.

69. Udgire, M.; Pathade, G. Evaluation of antimicrobial activities and phytochemical constituents of extracts of Valeriana wallichii. Asian J. Plant Sci. Res. 2013, 3, 55-59.

70. Hamlal, H., Subban, R. GC-MS, HPTLC and Antimicrobial analysis of root extracts of Pseudarthria Viscid Wight and Arn and Desmodium gangeticum (Linn) DC. Int. Res. J. Biol. Sci. 2012, 1, 57-65.

71. Laungsuwon, R. Chulalaksananukul, W. Chemical composition and antibacterial activity of extracts from freshwater green algae, Cladophora glomerata Kützing and Microspora floccosa (Vaucher) Thuret. J. BioSci. Biotech. 2014, 3, 211-218.

72. Marrez, D.A.; Sultan, Y.Y. Antifungal activity of the cyanobacterium Microcystis aeruginosa against mycotoxigenic fungi. J. Appl. Pharmaceut. Sci. 2016, 6, 191-198, https://doi.org/10.7324/JAPS.2016.601130.

73. Abdel-Rahman, G.N.; Sultan, Y.Y.; Hassoub, M.A.; Marrez. D.A. Cytotoxicity and antibacterial activity of the blue green alga Microcystis aeruginosa extracts against human cancer cell lines and foodborne bacteria. Egyptian J. Chem. 2020, 63, 4095-4105, https://doi.org/10.21608/EJCHEM.2020.42714.2862. 